\title{
Effect and Profitability of Foliar Application of Thiourea on Growth and Yield Attributes of Lentil (Lens culinaris L.) under Manipur Conditions of North-East, India
}

\author{
N. Premaradhya ${ }^{1 *}$, K.S. Shashidhar ${ }^{1}$, Samuel Jeberson ${ }^{1}$, \\ R. Krishnappa ${ }^{2}$ and Nabachandra Singh ${ }^{1}$ \\ ${ }^{1}$ College of Agriculture, Central Agricultural University, Imphal-795 004, Manipur, India \\ ${ }^{2}$ ICAR-RC NEH Region, Umiam-793 103, Meghalaya, India \\ *Corresponding author
}

A B S T R A C T

\begin{tabular}{|c|}
\hline Keywords \\
\hline $\begin{array}{l}\text { Lentil, Foliar spray, } \\
\text { Growth, Nutrient } \\
\text { uptake, Thiourea, } \\
\text { Profitability and Yield }\end{array}$ \\
\hline Article Info \\
\hline $\begin{array}{l}\text { Accepted: } \\
10 \text { April } 2018 \\
\text { Available Online: } \\
10 \text { May } 2018\end{array}$ \\
\hline
\end{tabular}

A field study was conducted to study the effect of sulphydryl bio-regulator like thiourea through foliar application on growth, yield and profitability of lentil in rice fallows. The experiment was laid out in randomized block design and replicated thrice with thirteen treatments including water spray (control), $2 \%$ urea, 500ppm and $1000 \mathrm{ppm}$ thiourea at different stages of crop growth. Results revealed that application of thiourea @ 1000ppm at pre-flowering and pod initiation recorded significantly increased shoot length $(34.1 \mathrm{~cm})$, total dry matter $\left(19.52 \mathrm{~g} \mathrm{plant}^{-1}\right)$, number of pods plant ${ }^{-1}(73.8)$ and thereby enhanced grain yield $\left(15.9 \mathrm{q} \mathrm{ha}^{-1}\right)$, straw yield $\left(33.0 \mathrm{q} \mathrm{ha}^{-1}\right)$ and protein yield $\left(325.4 \mathrm{~kg} \mathrm{ha}^{-1}\right)$ followed by recorded higher total nitrogen $\left(106.78 \mathrm{~kg} \mathrm{ha}^{-1}\right)$, phosphorus $\left(24.06 \mathrm{~kg} \mathrm{ha}^{-1}\right)$, potassium $\left(63.48 \mathrm{~kg} \mathrm{ha}^{-1}\right)$ and sulphur (6.74 $\left.\mathrm{mg} \mathrm{kg} \mathrm{soil}^{-1}\right)$ uptake. Moreover, this method of providing growth promoters and nutrients directly to metabolic sites (leaves) at critical stages fetched higher net returns (Rs. $53055 \mathrm{ha}^{-1}$ ) and yielded B: C ratio (2.95) over other treatments and control. The mean seed yield $(74.4 \%)$ in the above treatment was significantly higher compared to the control (no spray) and low dose of spray (500 ppm). Hence, foliar application of thiourea at $1000 \mathrm{ppm}$ at pre flowering and pod initiation is promising and profitable for economical lentil production by resource poor farmers of NEH Region.

\section{Introduction}

Rainfed agro-ecologies such as rice fallows are playing a major role in India and North eastern region for enhancing cropping intensity, food production and environmental security. Majority of this area (about $11.7 \mathrm{~m}$ ha) characterized by fragility under investment and traditional distressed crop production remains fallow after kharif season rice harvest, is majorly distributed in Bihar, Chhattisgarh, Jharkhand, Madhya Pradesh, Orissa, West Bengal and North Eastern Hill states. Among the candidate crops for this kind of stress prone rice fallows, Lentil (Lens culinaris M.) is one of the most suitable and befitting crop is widely cultivated across India and north-east India (Das et al., 2013; Layek et al., 2014). As seeds of lentil contain high value vegetative protein $(25 \%), 10 \%$ fat, $55.8 \%$ carbohydrates, 
$3.7 \%$ fiber, and 3.3\% ash (Purseglove, 1968; Wang et al., 2009) and short in duration preferred to cultivate under there unwarranted stressful condition during post monsoon season. Moreover as crop's water demands coincide with the end of the rabi season with reduced moisture, lentil often experiences considerable drought stress impact during reproductive development, which drastically reduces yields. Therefore, alleviating soil moisture stress during the critical crop growth stages and supplying essential nutrients during active growth is the key to improved production. In this way, numbers of abiotic stresses like drought and low fertility unprecedently hamper the growth and development of most of post monsoon crops. Several crop management practices to mitigate these stresses especially under changing climate are pertinent to workout substantial dividends (Ghosh et al., 2010 and Das et al., 2016).

Timely supply of growth regulating substances/growth regulators are known to influence a wide array of physiological parameters like alteration of plant architecture, assimilate partitioning, promotion of photosynthesis, uptake of nutrients (mineral ions), enhancing nitrogen metabolism, increased mobilization of assimilates to defined sinks, improved seed quality, induction of synchrony in flowering, and delayed senescence of leaves (Sharma et al., 2013). These growth regulators, when applied externally as foliar spray at proper crop growth stage in optimum concentration could play a significant role in increasing crop yield and quality of produce in different field crops (Nagasubramaniam et al., 2007). These plant growth regulators have been considered as software for plant development and improvement in crop productivity (Malik, 1995). Besides, foliar spray technique helps in fetching water and nutrients to the site of active food synthesis directly; leading no wastage, quick supply of food thereby regulates the plants source-sink relationships under stress or adverse conditions.

Thiourea is a nitrogen and sulfur containing compound with better water solubility and absorption potential is known to impart tolerance against prevailing abiotic stresses. Structurally, its molecule has two main functional groups; 'thiol' is reported vital for oxidative stress response and 'imino' strikingly capable to fulfil the increased $\mathrm{N}$ requirement under abiotic stress conditions. Thiols are well-known to maintain the disturbed redox state (-SH/-S-S- ratio) of the cell and its proper functioning under stress conditions (Nathawat et al., 2007 and Dhikwal et al., 2012). Its involvement and applicability has also been demonstrated for increasing grain filling under drought. At physiological level, this is directly associated with enhanced photosynthesis, increased metabolite translocation and co-ordinated regulation of plant's source to sink relationships (Pandey et al., 2013). Keeping these in consideration, the present investigation was undertaken to evaluate the effect of different concentration of sulfhydryl bio-regulator (thiourea) foliar spray at different stages of crop growth and yield attributes along with the economics of practicing this production technology of lentil under hilly terrains (Manipur) of subhimalayen conditions.

\section{Materials and Methods}

\section{Description of the Site}

One field experiment was conducted during rabi season of 2013-14 on clay loamy soil at university research farm of Central Agricultural University, Imphal, Manipur. The experimental site was medium in fertility (285.38, 324 and $16.32 \mathrm{~kg} \mathrm{ha}^{-1}$ available nitrogen, potassium and sulphur, respectively) except phosphorus (18.78 $\mathrm{kg} \mathrm{ha}^{-1}$ ) which is 
low and acidic in reaction. The climatic condition of Imphal valley is sub-tropical, crop experienced some showers during germination, establishment stage and active growth period with a mean rainfall of $283.3 \mathrm{~mm}$, highest in the month of October $(161.5 \mathrm{~mm})$ and no rainfall received during December and January, ambient temperature maximum and minimum temperature ranges is from 29.4 to $17.5{ }^{\circ} \mathrm{C}$ and 23.10 to $30.0{ }^{\circ} \mathrm{C}$ respectively and relative humidity ranging lowest in February $32 \%$, while the highest was recorded in the month of December $88.7 \%$. Lentil was used as test crop (variety PL-4) which sown on second fortnight of October by providing required inter $(30 \mathrm{~cm})$ and intra $(10 \mathrm{~cm})$ row spacing.

At each spot three-four seeds were dibbled and the seedlings were thinned out order to maintain the desired plant population. Herbicide spray of pendimethalin @ 1.0 kg a.i /ha as a pre emergence followed by one hand weeding at 30 days after sowing was carried out to keep crop weed free during the crop growth period and no pest and disease incidence was found.

\section{Treatments and experimental design}

The experiment was laid out in randomized block design and replicated thrice. Treatment combinations comprised of water, urea and thiourea spray at critical growth stages with varied concentrations including farmers practice viz., $\mathrm{T}_{1}$-Control (No spray), $\mathrm{T}_{2}$ Water spray at pre flowering, $\mathrm{T}_{3}$-Water spray at pod initiation, $\mathrm{T}_{4}$-Water spray at pre flowering + pod initiation, $\mathrm{T}_{5}$-Urea $2 \%$ spray at pre flowering, $\mathrm{T}_{6}$-Urea $2 \%$ spray at pod initiation, $\mathrm{T}_{7}$-Urea $2 \%$ spray at pre flowering + pod initiation, $\mathrm{T}_{8}$-Thiourea $500 \mathrm{ppm}$ at pre flowering, $\mathrm{T}_{9}$-Thiourea 500ppm at pod initiation, $\mathrm{T}_{10}$-Thiourea $500 \mathrm{ppm}$ at pre flowering + pod initiation, $\mathrm{T}_{11}$-Thiourea $1000 \mathrm{ppm}$ at pre flowering, $\mathrm{T}_{12}$-Thiourea
$1000 \mathrm{ppm}$ at pod initiation, $\mathrm{T}_{13}$ - Thiourea 1000 ppm at pre flowering + pod initiation. The recommended dose of nitrogen $\left(25 \mathrm{~kg} \mathrm{ha}^{-1}\right)$ phosphorus $\left(40 \mathrm{~kg} \mathrm{ha}^{-1}\right)$ and potassium $(20 \mathrm{~kg}$ $\mathrm{ha}^{-1}$ ) was applied as basal dose at the time of sowing. Treatments was applied at 52 DAS and 70 days after sowing (DAS) coinciding with pre flowering and pod initiation stage.

\section{Sampling, observations and analysis}

Observations on growth and yield parameters viz., plant height, productive branches/plant, shoot dry weight, number of pods plant ${ }^{-1}$, and 100 grain weight were recorded at maturity stage using the standard procedures. Similarly, data on number and dry weight of nodules/plant were recorded 45 and 60 DAS by digging and uprooting five plants from each plot. Dry weight of the nodules and shoots were recorded by drying samples in an oven at $60{ }^{\circ} \mathrm{C}$ for $72 \mathrm{hrs}$.

Biomass and seed yield (kg/ha) were computed based on seed weight per plot and computed for ha. All other agronomic and crop management aspects were followed as per the standard recommendations of the region. Economics of foliar application of urea and were worked out by using the current market price of inputs and lentil grain. The net return per hectare was worked out for all the treatments by subtracting the cost of cultivation from the gross return. B: C ratio was also calculated as ratio of gross return (Rs $\mathrm{ha}^{-1}$ ) over cost of cultivation ( $\mathrm{Rs} \mathrm{ha}^{-1}$ )

Statistical analyses of the data were carried out according to randomized block design and also as per methods suggested by Gomez and Gomez (1984). Fishers Least Significant Difference test was employed to test the significant differences between the means, at probability level $p \leq 0.05$ using the ANOVA. The non-significant treatment differences were denoted as NS (Panse and Sukhatme, 1985). 


\section{Results and Discussion}

As lentil is an ideal short duration pulse, it demands timely interventions of crop management practices to reduce the impact of stressful agro ecosystem.

In this study substantial improvement of all growth, yield attributes and profitability of crop was observed with increasing levels of bio regulators at critical stages.

\section{Growth attributes}

Foliar application of $1000 \mathrm{ppm}$ thiourea at pre flowering and pod initiation stages significantly increased overall shoot length $(34.1 \mathrm{~cm})$ and canopy growth which reflected in terms of enhanced number of branches per plant (7.07) and increased total dry matter accumulation (19.52 $\left.\mathrm{g} \mathrm{plant}^{-1}\right)$. Similarly, the higher number of nodules (16.3 plant $\left.{ }^{-1}\right)$ and nodule dry weight $\left(17.36 \mathrm{mg}\right.$ plant $\left.^{-1}\right)$ was observed under application of thiourea @500ppm at pre flowering and pod initiation and with thiourea @ $1000 \mathrm{ppm}$ at pre flowering, respectively (Table 1 ).

This positive changes in the crop might be ascribed to better growth and development of crop with thiourea treatment action possibly targeted the meristematic activity of apical tissues with stimulatory effects on cell division which causes increase in shoot length and cell number for improved leaf area (mostly by increased sulphur and nitrogen nutrition).

This provides greater canopy area for photosynthesis and biomass production with efficient partitioning of synthesised photoassimilates towards growing sinks and also increase the activity of Nitrate reductase (Havlin et al., (2004), Itanna, (2005), Yadav (2005) and Sharma et al., (2015). However, days to flowering and days to maturity was not significantly influenced by thiourea application.

\section{Yield and yield related attributes}

The yield attributes viz., number of pods plant $^{-1}$, number of seeds pod $^{-1}$, test weight, seed yield, stover yield and harvest index of lentil at harvest is significantly influenced by foliar application of thiourea (Table 2 and Fig. 1). Significantly higher pod plant ${ }^{-1}$ (73.8) was recorded by foliar application of thiourea @1000ppm at pre flowering and pod initiation. Similarly number of seeds pod ${ }^{-1}$ was recorded significantly higher with the application of thiourea @1000ppm at pre flowering and pod initiation (1.93) and thiourea @ 500ppm at pre-flowering plus pod initiation (1.93). This might be attributed to triggered nitrogen metabolism of crop and extended retention of moisture by the treated crop especially during moisture stress period, which might have helped to bear more number of pods plant ${ }^{-1}$ and number of seeds pod ${ }^{-1}$ at harvest.

The observed seed yield significantly varied due to foliar application but it was noticed highest at (15.9 $\left.\mathrm{qha}^{-1}\right)$ thiourea @ 1000ppm at pre flowering and pod initiation which was on par with three other treatments viz., thiourea @1000ppm at pod initiation (15.5q ha $\left.\mathrm{h}^{-1}\right)$, thiourea@500ppm at pre flowering plus pod initiation (15.3q ha $\left.{ }^{-1}\right)$ and thiourea @ 1000ppm at pre flowering $\left(14.8 \mathrm{q} \mathrm{ha}^{-1}\right)$ over lower seed yield $\left(9.1 \mathrm{q} \mathrm{ha}^{-1}\right)$ that was recorded with no spray (control). These treatments were significant in recording $74.43,70.04,67.50$ and 62.02 per cent increased seed yield over no spray (control). These results are in conformity with the findings of Anjum et al., (2008), Kumar et al., (2010), Bhunia et al., (2015) and Singh, R.P. and Dasharath Singh (2017) illustrating advantage of foliar application for incremental yield enhanced in pulses. 
Table.1 Effect of foliar application of thiourea on growth parameters of lentil in rice fallows of Manipur

\begin{tabular}{|c|c|c|c|c|c|c|c|}
\hline Treatments & $\begin{array}{l}\text { Plant height } \\
\text { at harvest } \\
(\mathrm{cm})\end{array}$ & $\begin{array}{l}\text { No. of branches } \\
\text { plant }^{-1} \text { at } \\
\text { harvest }\end{array}$ & $\begin{array}{c}\text { Total dry wt. at } \\
\text { harvest } \\
\left(\text { g. } \text { plant }^{-1}\right)\end{array}$ & $\begin{array}{l}\text { No. Nodules } \\
\text { plant }^{-1} \text { at } \\
45 \text { DAS }\end{array}$ & $\begin{array}{l}\text { Nodules dry wt. at } \\
\left.45 \text { DAS (mg plant }{ }^{-1}\right)\end{array}$ & $\begin{array}{c}\text { Days to } \\
50 \% \\
\text { flowering }\end{array}$ & $\begin{array}{l}\text { Days to } \\
\text { maturity }\end{array}$ \\
\hline $\mathrm{T}_{1}$ & 25.9 & 4.13 & 11.74 & 14.3 & 13.87 & 84 & 144 \\
\hline $\mathbf{T}_{3}$ & 27.3 & 4.27 & 13.82 & 14.5 & 15.25 & 84 & 143 \\
\hline $\mathrm{T}_{4}$ & 28.1 & 4.67 & 14.78 & 14.6 & 14.8 & 83 & 143 \\
\hline$T_{5}$ & 28.8 & 4.67 & 15.26 & 14.8 & 14.66 & 81 & 142 \\
\hline $\mathbf{T}_{7}$ & 30.1 & 5.6 & 16.62 & 15.9 & 16.3 & 78 & 141 \\
\hline $\mathrm{T}_{8}$ & 29.9 & 5.73 & 16.47 & 15.5 & 16.36 & 79 & 140 \\
\hline $\mathrm{T}_{9}$ & 30.4 & 5.93 & 17.16 & 15.5 & 16.16 & 79 & 139 \\
\hline$T_{10}$ & 32.7 & 6.6 & 18.84 & 16.3 & 16.94 & 77 & 136 \\
\hline $\mathbf{T}_{11}$ & 31.2 & 6.6 & 18.66 & 15.9 & 17.36 & 78 & 137 \\
\hline$T_{12}$ & 32.1 & 7.07 & 19.11 & 16.1 & 16.7 & 78 & 135 \\
\hline
\end{tabular}

Treatment details:

T 1 - Control (No spray)

$\mathrm{T}_{2}$ - Water spray at pre flowering (45-55 DAS)

$\mathrm{T}_{3}$ - Water spray at pod initiation (65-75 DAS)

$\mathrm{T}_{4}$ - Water spray at pre flowering (45-55 DAS) + pod initiation (6575 DAS)

$\mathrm{T}_{5}$ - Urea $2 \%$ spray at pre flowering (45-55 DAS)

$\mathrm{T}_{6}$ - Urea $2 \%$ spray at pod initiation (65-75 DAS)

$\mathrm{T}_{7}$ - Urea $2 \%$ spray at pre flowering (45-55 DAS) + pod initiation (65-75 DAS)
$\mathbf{T}_{\mathbf{8}}$ - Thiourea 500ppm at pre flowering (45-55 DAS)

$\mathbf{T}_{\mathbf{9}}$ - Thiourea 500ppm at pod initiation (65-75DAS)

$\mathbf{T}_{10}$ - Thiourea $500 \mathrm{ppm}$ at pre flowering (45-55 DAS) + pod initiation (65-75 DAS)

$\mathbf{T}_{11}$ - Thiourea 1000ppm at pre flowering (45-55 DAS)

$\mathbf{T}_{12}$ - Thiourea 1000ppm at pod initiation (65-75 DAS)

$\mathbf{T}_{13}$ - Thiourea $1000 \mathrm{ppm}$ at pre flowering (45-55 DAS) + pod initiation (6575 DAS) 
Table.2 Effect of foliar applications of thiourea on yield, yield parameters, protein content and protein yield of Lentil in rice fallows of Manipur

\begin{tabular}{|c|c|c|c|c|c|c|c|c|c|}
\hline Treatments & $\begin{array}{l}\text { No. of pods } \\
\text { plant }^{-1}\end{array}$ & $\begin{array}{c}\text { No. of } \\
\text { seeds pod }\end{array}$ & $\begin{array}{c}100 \\
\text { seeds } \\
\text { weight }\end{array}$ & $\begin{array}{c}\text { Seed } \\
\text { yield } \\
\left(\mathbf{q} \mathbf{h a}^{-1}\right)\end{array}$ & $\begin{array}{c}\% \\
\text { Increase } \\
\left(\mathbf{q} \mathbf{h a}^{-1}\right)\end{array}$ & $\begin{array}{c}\text { Stover } \\
\text { yield } \\
\left(\mathbf{q} \mathbf{h a}^{-1}\right)\end{array}$ & $\begin{array}{c}\text { Harvest } \\
\text { Index } \\
(\%)\end{array}$ & $\begin{array}{c}\text { Protein } \\
\text { Content } \\
(\%)\end{array}$ & $\begin{array}{c}\text { Protein } \\
\text { Yield } \\
\left(\mathrm{kg} \mathrm{ha}^{-1}\right)\end{array}$ \\
\hline$T_{1}$ & 46.7 & 1.4 & 1.71 & 9.1 & - & 18.3 & 33.3 & 20.8 & 190.0 \\
\hline$T_{3}$ & 49.5 & 1.65 & 1.77 & 9.8 & 6.9 & 19.3 & 33.6 & 20.3 & 198.3 \\
\hline$\overline{T_{4}}$ & 53.5 & 1.67 & 1.78 & 10.1 & 10.7 & 20.2 & 33.3 & 20.5 & 206.9 \\
\hline$T_{5}$ & 52.8 & 1.73 & 1.83 & 10.3 & 12.8 & 21 & 32.9 & 21.6 & 222.9 \\
\hline$\overline{T_{7}}$ & 61.3 & 1.8 & 1.86 & 12.7 & 38.8 & 26.9 & 32.4 & 20.4 & 258.7 \\
\hline$T_{8}$ & 63.2 & 1.8 & 1.82 & 13.0 & 42.8 & 26 & 33.4 & 21.4 & 279.1 \\
\hline$T_{9}$ & 64.0 & 1.87 & 1.87 & 14.4 & 57.5 & 28.1 & 33.9 & 20.7 & 297.8 \\
\hline$T_{10}$ & 72.5 & 1.93 & 1.85 & 15.3 & 67.5 & 30.7 & 33.4 & 20.2 & 308.6 \\
\hline$T_{11}$ & 70.0 & 1.87 & 1.88 & 14.8 & 56.6 & 29.6 & 32.5 & 20.2 & 299.1 \\
\hline$T_{12}$ & 72.7 & 1.9 & 1.98 & 15.5 & 70.0 & 30.7 & 33.6 & 20.7 & 321.7 \\
\hline
\end{tabular}

Treatment details:

T 1 - Control (No spray)

$\mathrm{T}_{2}$ - Water spray at pre flowering (45-55 DAS)

$\mathrm{T}_{3}$ - Water spray at pod initiation (65-75 DAS)

$\mathrm{T}_{4}$ - Water spray at pre flowering (45-55 DAS) + pod initiation (65-75 DAS)

$\mathrm{T}_{5}$ - Urea $2 \%$ spray at pre flowering (45-55 DAS)

$\mathrm{T}_{6}$ - Urea $2 \%$ spray at pod initiation (65-75 DAS)

$\mathrm{T}_{7}$ - Urea $2 \%$ spray at pre flowering (45-55 DAS) + pod initiation (65-75

DAS)

$\mathbf{T}_{\mathbf{8}}$ - Thiourea 500ppm at pre flowering (45-55 DAS)

$\mathbf{T}_{\mathbf{9}}$ - Thiourea 500ppm at pod initiation (65-75DAS)

$\mathbf{T}_{10}$ - Thiourea $500 \mathrm{ppm}$ at pre flowering (45-55 DAS) + pod initiation (65-75 DAS)

$\mathbf{T}_{\mathbf{1 1}}$ - Thiourea 1000ppm at pre flowering (45-55 DAS)

$\mathbf{T}_{\mathbf{1 2}}$ - Thiourea 1000ppm at pod initiation (65-75 DAS)

$\mathbf{T}_{13}$ - Thiourea $1000 \mathrm{ppm}$ at pre flowering (45-55 DAS) + pod initiation (65-75

DAS) 
Table.3 Effect of foliar applications of thiourea on Nutrient uptake and Economics of lentil in rice fallows of Manipur

\begin{tabular}{|c|c|c|c|c|c|c|}
\hline Treatments & Nitrogen $\left(\mathrm{Kg} \mathrm{ha}^{-1}\right)$ & $\begin{array}{l}\text { Phosphorus } \\
\left(\mathrm{Kg} \mathrm{ha}^{-1}\right)\end{array}$ & $\begin{array}{l}\text { Potassium } \\
\left(\mathrm{Kg} \mathrm{ha}^{-1}\right)\end{array}$ & $\begin{array}{l}\text { Sulphur } \\
\left(\mathrm{Kg} \mathrm{ha}^{-1}\right)\end{array}$ & $\begin{array}{c}\text { Net returns } \\
\left(\operatorname{Rs~ha}^{-1}\right)\end{array}$ & B:C Ratio \\
\hline $\mathbf{T}_{1}$ & 86.85 & 12.33 & 52.47 & 2.12 & 24955 & 1.54 \\
\hline $\mathbf{T}_{2}$ & 90.05 & 12.70 & 54.10 & 2.41 & 25277 & 1.53 \\
\hline $\mathbf{T}_{3}$ & 92.81 & 13.44 & 54.89 & 2.42 & 27443 & 1.66 \\
\hline $\mathbf{T}_{4}$ & 91.74 & 13.58 & 55.41 & 2.67 & 28615 & 1.69 \\
\hline $\mathbf{T}_{5}$ & 95.39 & 14.72 & 56.18 & 3.65 & 29721 & 1.78 \\
\hline$T_{6}$ & 99.57 & 15.21 & 56.25 & 3.34 & 32622 & 1.96 \\
\hline $\mathbf{T}_{7}$ & 97.62 & 17.24 & 56.29 & 4.38 & 39886 & 2.32 \\
\hline $\mathbf{T}_{8}$ & 102.06 & 19.39 & 57.18 & 4.62 & 41593 & 2.43 \\
\hline $\mathrm{T}_{9}$ & 102.01 & 20.89 & 58.11 & 5.23 & 47658 & 2.78 \\
\hline $\mathbf{T}_{10}$ & 105.09 & 23.02 & 62.95 & 6.43 & 50795 & 2.81 \\
\hline $\mathbf{T}_{11}$ & 104.65 & 22.95 & 61.26 & 6.41 & 46681 & 2.64 \\
\hline $\mathrm{T}_{12}$ & 105.53 & 23.23 & 61.49 & 6.48 & 52199 & 2.95 \\
\hline $\mathbf{T}_{13}$ & 106.78 & 24.06 & 63.48 & 6.74 & 53055 & 2.84 \\
\hline SEM \pm & 2.31 & 0.38 & 1.82 & 0.17 & - & - \\
\hline C D (0.05) & 6.74 & 1.12 & 5.30 & 0.49 & - & - \\
\hline
\end{tabular}

\begin{tabular}{|c|c|}
\hline Treatment details: & \\
\hline \multicolumn{2}{|l|}{$T_{1}$ - Control (No spray) } \\
\hline $\mathrm{T}_{2}$ - Water spray at pre flowering (45-55 DAS) & $\mathbf{T}_{\mathbf{8}}$ - Thiourea 500ppm at pre flowering (45-55 DAS) \\
\hline $\mathrm{T}_{3}$ - Water spray at pod initiation (65-75 DAS) & $\mathbf{T}_{9}-$ Thiourea 500ppm at pod initiation (65-75DAS) \\
\hline $\begin{array}{l}\text { T }_{4} \text { - Water spray at pre flowering ( } 45-55 \text { DAS) + pod initiation (65- } \\
75 \text { DAS) }\end{array}$ & $\begin{array}{l}\mathbf{T}_{10} \text { - Thiourea } 500 \text { ppm at pre flowering }(45-55 \text { DAS })+\text { pod initiation }(65-75 \\
\text { DAS) }\end{array}$ \\
\hline $\mathrm{T}_{5}$ - Urea $2 \%$ spray at pre flowering (45-55 DAS) & $\mathbf{T}_{11}$ - Thiourea $1000 \mathrm{ppm}$ at pre flowering (45-55 DAS) \\
\hline $\mathrm{T}_{6}$ - Urea $2 \%$ spray at pod initiation (65-75 DAS) & $\mathbf{T}_{\mathbf{1 2}}$ - Thiourea $1000 \mathrm{ppm}$ at pod initiation (65-75 DAS) \\
\hline $\begin{array}{l}T_{7} \text { - Urea } 2 \% \text { spray at pre flowering }(45-55 \text { DAS })+\text { pod initiation } \\
(65-75 \text { DAS) }\end{array}$ & $\begin{array}{l}\mathbf{T}_{13} \text { - Thiourea } 1000 \mathrm{ppm} \text { at pre flowering }(45-55 \text { DAS })+\text { pod initiation }(65-75 \\
\text { DAS) }\end{array}$ \\
\hline
\end{tabular}


Fig.1 Number of pods, Seed yield and Stover yield as influenced by different dose of thiourea sprays on lentil in rice fallows of Manipur

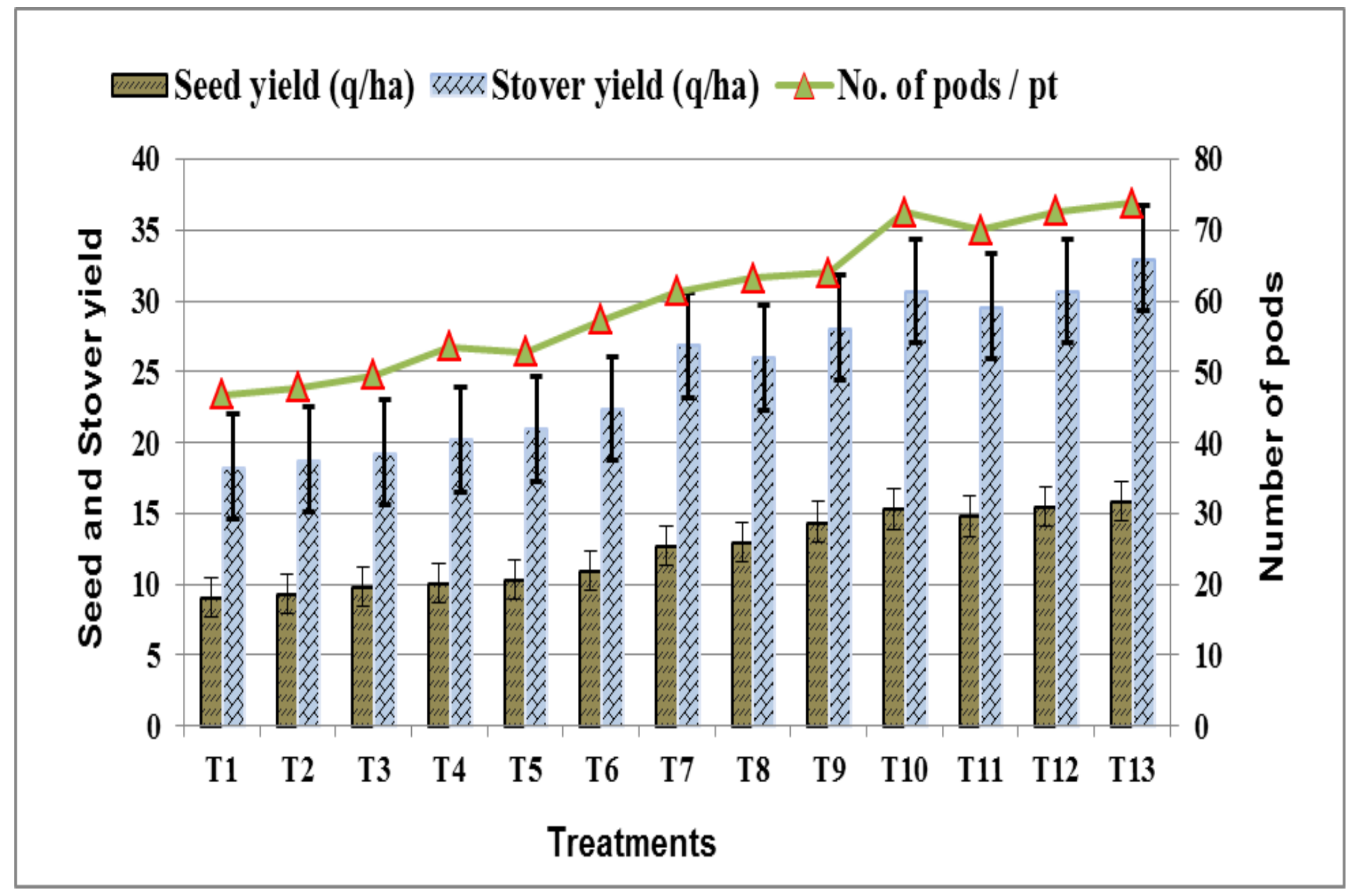




\section{Protein content and protein yield}

An appraisal of data revealed that sulphydryl bio-regulator (thiourea) has not significantly influenced the protein content of grain. However, protein yield was significantly increased with application of thiourea @ 1000ppm at pre flowering plus pod initiation $\left(324.4 \mathrm{~kg} \mathrm{ha} \mathrm{ha}^{-1}\right)$ followed by thiourea @ $1000 \mathrm{ppm}$ at pod initiation (321.7 $\mathrm{kg} \mathrm{ha}^{-1}$ ) over water spray at pre -flowering stage and control (186.4 kgha ${ }^{-1}$ and $\left.190.0 \mathrm{~kg} \mathrm{ha}^{-1}\right)$, respectively (Table 2). The protein yield increase might be due to applied thiourea favorably affects nitrogen metabolism in lentil. In contravention, application of SH- compounds had significant influenced the protein content and protein yield of grain by Singh, 2007 and Meena and Sharma, 2010.

\section{Nutrient uptake}

Foliar application of thiourea @ 1000ppm at pre flowering and pod initiation stages increased the uptake of total nitrogen $\left(106.78 \mathrm{~kg} \mathrm{ha}^{-1}\right)$, total phosphorus (24.06 $\left.\mathrm{kg} \mathrm{ha}^{-1}\right)$, total potassium $\left(63.48 \mathrm{~kg} \mathrm{ha}^{-1}\right)$ and total sulphur $\left(6.74 \mathrm{~kg} \mathrm{ha}^{-1}\right)$ significantly which was being recorded at par with other thiourea treatments. However, significantly lower uptake of N, P, K and S was recorded in control (no spray) treatment $(86.85$ $\mathrm{kg} \mathrm{ha}^{-1}, 12.33 \mathrm{~kg} \mathrm{ha}^{-1}, 52.47 \mathrm{~kg} \mathrm{ha}^{-1}$ and $2.12 \mathrm{~kg}$ $\mathrm{ha}^{-1}$, respectively). This was 22.94, 95.15, 20.98 , and $218.14 \%$ higher over control (Table $3)$. Increased total uptake of N, P, K and S may be attributed to increased activity of source with increased photosynthates and other nutrient metabolics and also to activation of microbial population in soil which is responsible for mobilizing essential nutrients (Balai and keshwa, 2011).

From above results, pre-flowering and pod initiation seems to better stage for thiourea application as leaf size and demand/hunger of the crop is maximum for better absorption of applied thiourea and for increased synthesis and accumulation of metabolites like growth hormones to stimulate the metabolism for increased biomass production. The positive effect of thiourea seems to be mediated through enhanced photosynthetic efficiency besides more efficient carbohydrate and nitrogen metabolism (Garg et al., 2003).

\section{Economics}

Maximum net return of Rs. $53055 \mathrm{ha}^{-1}$ and B: C ratio of 1: 2.95 were noticed in foliar spray of thiourea @1000ppm at pre flowering plus pod initiation and thiourea application@1000 ppm at pod initiation, respectively. Moreover, lowest net return of Rs. $24955 \mathrm{ha}^{-1}$ and $\mathrm{B}$ : C ratio 1.54 was recorded under control (no spray) (Table 3). This might be due to greater seed yield and fodder with application and use of thiourea which serve as viable alternative to overcome the soil barrier in nutrient and water deficiency. This simple, easy and promising production technique may lead to on-farm adaptation of such as sulfhydryl compound (Rehman et al., 2013) by resource poor hill farmer of the NEH region.

Thiourea is an important compound with biologically important thiol and amino groups, which remarkably differs over urea application, as its applicability proved for significance in the modulation of gene expression, induction and activation of antioxidative defense system which results in improvised photosynthetic capacity and leaf gas exchange properties of crops under stressful environments. Foliar application of thiourea @ $1000 \mathrm{pm}$ at pre flowering plus pod initiation stages and pod initiation alone, and @ 500ppm at pre flowering and pod initiation stages significantly improved the growth and the yield of lentil at hilly conditions of NEH region, through better root growth and adaptability with better nutrient uptake which consequently resulted in higher net returns and increased benefit cost ratio. Improved agronomic technologies like cost effective foliar application techniques could possibly help in utilizing untapped potential of rice fallow through expansion of pulses in this NEH region. 


\section{Acknowledgments}

The authors are grateful to AICRP-MULLaRP, Manipur Centre and college of Agriculture, C.A.U, Imphal for the necessary help and facilities provided for conducting the study.

\section{References}

Anjum, F., A. Wahid, F. Javed and Arshad, M. (2008). Influence of foliar applied thiourea on flag leaf gas exchange and yield parameters of bread wheat (Triticuma estivum) cultivars under salinity and heat stresses. International Journal of agriculture and Biology, 10: 619-26.

Balai and Keshwa (2011). Effect of thiourea on yield and nutrient uptake of coriander (Coriandrum sativum L.) varieties under normal and late sown conditions. $J$. Spices and Aroma. Crops, 20(1): 34-37.

Bhunia, S. R., Verma, I.M., Sahu, M. P., Sharma, N. C. and Balai, K. (2015). Effect of drip irrigation and bioregulators on yield, economics and water use of fenugreek (Trigonella foenum-graecum). Journal of Spices and Aromatic Crops, 24 (2): 102-105.

Das, A., Ramkrushna, G.I., Ngachan, S.V. and Munda, G.C. (2013). Resource Conservation Technologies in Pulse based Cropping Systems in NEH region (In) Resource Conservation Technology in Pulses, pp. 43-57, Ghosh, P.K., Kumar, N., Venkatesh, M.S., Hazra, K.K. and Nadarajan (Eds), Scientific Publishers, Jodhpur, Rajasthan, India.

Das, A., Subhash Babu, Yadav, G.S., Ansari, M.A., Singh, R., Baishya, L.K., Rajkhowa, D.J. and Ngachan, S.V. (2016). Status and strategies for pulses production for food and nutritional security in north eastern region of India. Indian J Agronomy 61 (special issue): 4357.

Dhikwal, S.R., Kumawat, S.M., Das, S and Jat, B.L. (2012). Effect of bio-regulators application on productivity of barley
(Hordeum vulgare L.) in arid conditions of western Rajasthan. Forage Res., 38(2): 106-111.

Garg, B.K., Burman, U. and Kathju. S. (2003). Influence of thiourea on photosynthesis, nitrogen metabolism and yield of clusterbean under moisture deficit condition. In: $2^{\text {nd }}$ Int. Congress of plant physiology, IARI, New Delhi: 158.

Ghosh, P.K., Das, Anup, Saha, R., Enboklang, K., Tripathi, A.K., Munda, G.C. and Ngachan, S.V. 2010. Conservation agriculture towards achieving food security in North East India. Curr. Sci., 99 (7): 915-921.

Gomez, K.A. and Gomez, A.A. (1984). Statistical Procedures for Agricultural Research. $2^{\text {nd }}$ edn. John Wiley \& Sons, New York.

Havlin, J.L, Beaton, J.D, Tisdale, S.L and Nelson, W.L. (2004). Soil fertility and fertilizers, an introduction to nutrient management, 7th edn. Pearson Education, Singapore.

Itanna, F. (2005). Sulfur distribution in five Ethiopian Rift Valley soils under humid and semi-arid climate. J. Arid Environ, 62: 597-612.

Kumar, P., Singh, F. and Kumar, R. (2010). Studies on Agro-techniques for yield maximization of pearl millet (Pennisetum glaucum) under rainfed conditions. Progress. Agric., 10(1):164-165.

Layek, J., Chowdhury, S., Ramkrushna, G.I. and Das, A. (2014). Evaluation of Different Lentil Cultivars in Lowland Rice Fallow under No-Till System for Enhancing Cropping Intensity and Productivity. Indian $J$ Hill Farming. 27(2): 4-9.

Malik, C. P. (1995). Plant growth regulators; software for plant development and crop productivity (pp. 1-5). Presidential address (Botany section) Indian Science Congress Association.

Meena, B.S. and Sharma, D.D (2010). Effect of phosphorus sources, solubilizers and bioregulators on dry matter, yield and 
quality of pigeon pea [Cajanus cajan (L.)]. Legume Res., 33(4):263-268.

Nagasubramaniam, A., Pathmanabhan, G., and Mallika, V. (2007). Studies on improving production potential of baby corn with foliar spray of plant growth regulators. Annual Review of Plant Physiology, 21; 154-157.

Nathawat, N.S., Nair, J.S., Kumawat, S.M., Yadava, N.S., Singh, G., Ramaswamy, N.K., Sahu M.P. and D'souza, S.F. (2007). Effect of seed soaking with thiols on the antioxidant enzymes and photosystem activities in wheat subjected to water stress. Biol. Plant., 51: 93-97.

Pandey M, Srivastava AK, D'Souza SF and Suprasanna P (2013) Thiourea, a ROS scavenger, regulates source-to-sink relationship for enhanced crop yield and oil content in Brassica juncea (L.). PloS One 8(9): e73921.

Panse, V.G. and Sukhatme, P.V. (1985). Statistical methods, for agricultural workers. Forth Enlarged Edition. ICAR Publication, New Delhi.

Purseglove, J.W. (1968). Tropical Crops Dicotyledons 1. Longmann, Green and Co. Ltd. p. 279.

Rehman, H., Iqbal, Q., Farooq, M., Wahid, A., Afzal, I. and Basra, S.M.A. (2013). Sulphur application improves the growth, Seed yield and oil quality of canola. Acta Physiol, Plant, 35 (10): 2999-3006.

Sharma, K. M., Asarey, R. and Verma, H. (2015). Response of wheat (Triticum aestivum L.) to the foliar applied brassinosteroid and thiourea with recommended fertilization practice on farmer's fields. Plant Archives, 15 (2):729-732.

Sharma, P., Sardana, V., and Sukhvinder Singh, K. (2013). Dry matter partitioning and source-sink relationship as influenced by foliar sprays in groundnut. The Bioscan, 8; 1171-1176.

Singh, B.R. (2007). Effect of thiourea and molybdenum on productivity of mothbean [Vigna acontifolia (Jacq.) Marechal]. M.Sc. (Agri.) Thesis, Rajasthan Agricultural University, Bikaner.

Singh, R.P. and Dasharath Singh. 2017. Response of Lentil to Thiourea Application under Rain Fed Conditions of Central India. Int.J.Curr.Microbiol. App.Sci. 6(3): 2556-2560.

Wang, N., D.W. Hatcher, R. Toews and E.J. Gawalko. 2009. Influence of cooking and dehulling on nutritional composition of several varieties of lentils (Lens culinaris). LWT - Food Science and Technology, 42: 842-848.

Yadav, L.R. (2005). Effect of bioregulators on productivity of wheat (Triticum aestivum L.) varieties under normal and late sown conditions. Ph.D. Thesis, Submitted to Rajasthan Agricultural University, Bikaner, Rajasthan.

\section{How to cite this article:}

Premaradhya, N., K.S. Shashidhar, Samuel Jeberson, R. Krishnappa and Nabachandra Singh. 2018. Effect and Profitability of Foliar Application of Thiourea on Growth and Yield Attributes of Lentil (Lens culinaris L.) under Manipur Conditions of North-East, India. Int.J.Curr.Microbiol.App.Sci. 7(05): 1040-1050. doi: https://doi.org/10.20546/ijcmas.2018.705.129 